\title{
Distribution of Phosphorus Fractions down the Soil Depth in the Savanna Zone of Nigeria
}

\author{
A. O. Ojo ${ }^{1}$, V. O. Aduramigba-Modupe ${ }^{1}$, O. D. Adeoyolanu ${ }^{1}$, O. A. Denton ${ }^{1}$, A. O. Oyedele ${ }^{1}$, A. O. Tayo-Aruna \\ \& I. O. Fademi ${ }^{1}$ \\ ${ }^{1}$ Institute of Agricultural Research and Training, Moor Plantation, Apata, Ibadan, Nigeria \\ Correspondence: A. O. Ojo, Institute of Agricultural Research and Training, P.M.B. 5029, Moor Plantation, \\ Apata, Ibadan, Nigeria. E-mail: remia_ode@yahoo.com
}

Received: May 30, 2017

doi:10.5539/jas.v9n9p94
Accepted: July 7, $2017 \quad$ Online Published: August 15, 2017

URL: https://doi.org/10.5539/jas.v9n9p94

\begin{abstract}
The distribution of phosphorus (P) fractions down the soil depth varies depending on the soil type as being affected by the surrounding soil management practices. A $10 \mathrm{~km}$ by $10 \mathrm{~km}$ site was chosen in the savanna zone of Nigeria for the study. Modal soil profile pits were dug to identify the different soil types while soil sampling was done at $0-20 \mathrm{~cm}, 20-40 \mathrm{~cm}, 40-80 \mathrm{~cm}$ and $80-120 \mathrm{~cm}$ depth. Resin P was the largest extractable P fraction while residual $\mathrm{P}$ was the least in the soil series characterized, down the soil depth. Fractionation results showed that there was variation down the soil depth. The conc. HCl-Pi was not observed at the $0-20 \mathrm{~cm}$ depth, $\mathrm{NaHCO}_{3}$-Pi and Po was small while NaOH-Pi and Po was observed at this depth. Initial decrease at the 20-40 $\mathrm{cm}$ depth was observed for most of the $\mathrm{P}$ fractions while more of the $\mathrm{P}$ fractions were observed at the $40-80 \mathrm{~cm}$ depth. The values observed at the $80-120 \mathrm{~cm}$ depth was however small compared to other soil depth. Resin P was the sink of $\mathrm{P}$ and would serve as a reserve of $\mathrm{P}$ in the soil series. However, organic and inorganic $\mathrm{P}$ extractable with $\mathrm{NaOH}$ i.e. $\mathrm{NaOH} \mathrm{Pi}$ and $\mathrm{Po}$ which were high at the $0-20 \mathrm{~cm}$ depth would be mainly responsible for the availability of $\mathrm{P}$ in the soil solution for plant uptake.
\end{abstract}

Keywords: phosphorus fractions, soil type, soil depth, savanna zone

\section{Introduction}

Phosphorus (P) is the one major element in soil which must be supplied almost entirely by the parent material of the unfertilized soils because of low atmospheric returns. Also, $\mathrm{P}$ is a main limiting nutritional factor in high weathered soils, like most tropical areas and is characterized by a low content of available $\mathrm{P}$ with high $\mathrm{P}$ fixation. The usefulness of phosphorus fractions as an indicator of soil fertility and the degree of pedogenesis have long been established (Ridley, 1984; Loganathan \& Sutton, 1987). Transformation and losses of P has been found to be influenced by the nature of the P in the parent material (Raji, 2006) and the relative abundance of the various fractions phosphorus fractions reflects the degree of soil weathering and development. Soil P is generally categorized into three types-solution P, labile P and non-labile P. the labile P fractions are more than the soluble Ps and they are not strongly adsorbed in the soil and may enter the soluble phase relatively quickly. Stable or the non-labile $\mathrm{P}$ fractions on the other hand are unavailable to plants and constitutes the greatest fraction of the total soil P. With time, due to weathering among several factors like land use/cropping systems and the past fertilizer use, a small amount of the non-labile P reacts chemically to become labile P and soluble P. In a study on soil profiles in selected soils of the derived savanna and northern guinea savanna zones of Nigeria, total $\mathrm{P}$ was found to vary among the soil profiles and decrease as the soil depth increases while resin P was significantly increased by organic matter (Nwoke et al., 2004). The increase or decrease in the earlier stated forms of $P$ fractions could be attributed to various factors such as fertilizer application, land use, organic matter build-up, tillage practices among various factors (Bunermann et al., 2006). An example was found in the research of Scherer and Sharma (2002) where they discovered that residual P for instance decreased or increased due to application of mineral and organic fertilizers after 38 years of cultivation. Beck and Sanchez (1994) reported that NaOH-Pi was the dominant fraction related to availability of $P$ to plants in a continuously cultivated and fertilized cropping system for over 18 years in an Ultisol. Also, increasing application or deposition of organic residues allowed $\mathrm{P}$ to be retained in more labile P fractions for a longer period (Uygur \& Karabatak, 2009). Land use and soil management practices have been found to influence soil $\mathrm{P}$ through processes such as oxidation, mineralization 
and leaching (Liu et al., 2010). However, in some West Africa soils, resin P for instance has been found to be generally low (mean of $5 \mathrm{mg} \mathrm{ka}^{-1}$ on the top soil) and decrease with depth. In Nigeria, like other tropical countries, widespread P studies have shown that the soils are generally deficient in available P (Igwe, 2001) but to date majority of soil $\mathrm{P}$ research has been focused on the topsoil and little attention has been given to the subsoil P pools which may act as an additional source of plant available P. For instance, Wang et al. (2007) suggested that subsoil sampling should be considered in order to improve the monitoring of soil $\mathrm{P}$ status. This study is however to determine the distribution of forms of $\mathrm{P}$ as affected by location and depth in the savanna zone of Nigeria.

\section{Materials and Methods}

\subsection{Background Study}

It was observed that consistently animals such as cow as continuously grazed on the farms where the soil profile was dug across the different agro-ecological zones. However, in the derived and Sudan savanna zones it was discovered that farmers have continuously applied inorganic fertilizer was the usual practice on the farmlands.

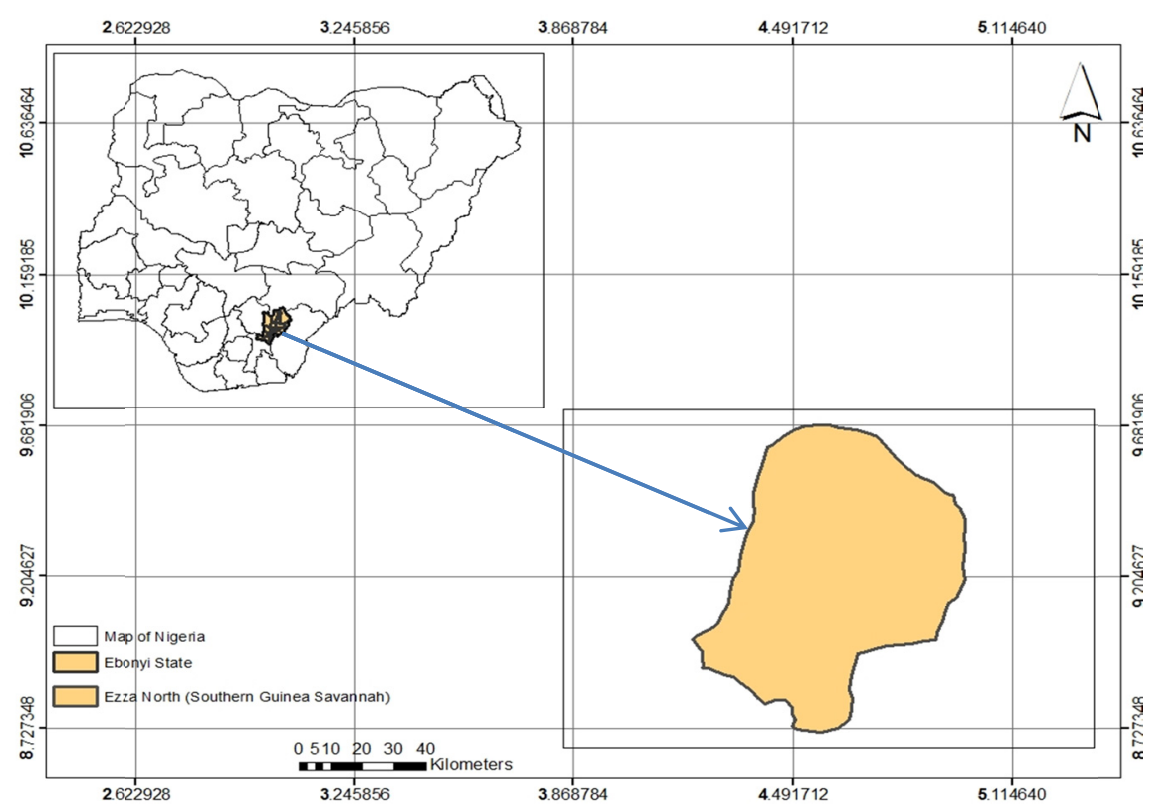

Figure 1. Map showing the agro-ecological zone

\subsection{Soil Characterization}

Diagnostic survey of existing farming systems related to soil and water management was carried out after which a $10 \mathrm{~km} \times 10 \mathrm{~km}$ site was chosen for soil survey. Free survey method was employed to map the soils. Auger soil examinations were carried out along different toposequences for soil types identification and boundary placement. Modal soil profile pits were dug based on the most representative auger examination points for each of the identified soil types. The soil profiles were described according to the FAO guidelines (2006). On the whole six modal soil profile pits (representing three soil types) were dug, described and sampled. The three soil series are: Okpanam series, Afia Mpko series and Katcha series. The peculiarity of the soil types to water table barrier and hardpans were similar and the soil was sampled at $0-20 \mathrm{~cm}, 20-40 \mathrm{~cm}, 40-80 \mathrm{~cm}$ and $80-120 \mathrm{~cm}$ depth. The soils were classified into series level using the approaches of Moss (1957) and Murdoch et al. (1976) and to higher level using WRB (2014) (Table 1). 
Table 1. Identified soil series in the agro-ecological zone and their FAO classifications

\begin{tabular}{ll}
\hline Soil Series & Soil type (FAO) \\
\hline Katcha & Ferric Luvisol \\
Okpananam & Ferric Luvisol \\
Afia Mpko & Orthic Fluvisol \\
\hline
\end{tabular}

\subsection{Fractionation of $P$}

Soil to extractant used was what Tiessen and Moir (1993) recommended i.e. 1:60. Two resin strips were added to $10 \mathrm{ml}$ of distilled water and shaken for $16 \mathrm{hrs}$. After retrieving the strips and washing adhering soil with distilled water into the centrifuge tube, $\mathrm{P}$ was extracted from the resin with $10 \mathrm{ml} 0.5 \mathrm{M} \mathrm{HCl}$ for $16 \mathrm{hrs}$. The soil suspension was centrifuged at $2,000 \mathrm{rpm}$ for $10 \mathrm{~min}$ and the supernatant was discarded. Consecutively, extractions were made with $10 \mathrm{ml}$ of $0.5 \mathrm{M} \mathrm{NaHCO}_{3}$ (adjusted to pH8.5), $0.1 \mathrm{M} \mathrm{NaOH}$, and $1 \mathrm{M} \mathrm{HCl}$, each separately shaken for $16 \mathrm{hrs}$ and centrifuged at 2,000 rpm. The supernatant was carefully decanted and stored in the refrigerator for analysis. Two milliliters of concentrated $\mathrm{HCl}$ was added to the soil and the tubes were placed in a water bath at $80{ }^{\circ} \mathrm{C}$ for $10 \mathrm{~min}$. After removal, the suspension was allowed to cool down for $1 \mathrm{~h}$, while shaking the tubes every $15 \mathrm{~min}$ by hand. After adding $1 \mathrm{ml}$ of concentrated $\mathrm{HCl}$ to the same tubes, they were centrifuged at 2,000 rpm for $10 \mathrm{~min}$ and the supernatant was poured into a 10-ml volumetric flask. This was repeated with $2 \mathrm{ml}$ of distilled water. The volumetric flask was then made up to volume with distilled water. After adding $3 \mathrm{ml}$ of concentrated $\mathrm{HNO}_{3}$ and $1 \mathrm{ml}$ of concentrated $\mathrm{HClO}_{4}$ the soil was transferred to a crucible and placed in a sand bath at $200{ }^{\circ} \mathrm{C}$ for $16 \mathrm{hrs}$. After the soil cooled down, $2 \mathrm{ml}$ of $5 \mathrm{M} \mathrm{HNO}_{3}$ was added to the crucible, filtered into a $10-\mathrm{ml}$ volumetric flask and made up to volume with $\mathrm{HNO}_{3}$.

Inorganic P in the resin-, dilute-acid-, acid-, and residual-P extracts was measured directly using the molybdate ascorbic acid method (Murphy \& Riley, 1962) on a spectrophotometer at $712 \mathrm{~nm}$. For the alkaline extracts, 1.2 and $0.3 \mathrm{ml}$ of $0.9 \mathrm{M} \mathrm{H}_{2} \mathrm{SO}_{4}$ was added to $2 \mathrm{ml}$ of bicarbonate and hydroxide extract, respectively. After centrifugation at $4,000 \mathrm{rpm}$ for $20 \mathrm{~min}$ and cooling in a refrigerator for $30 \mathrm{~min}$, inorganic $\mathrm{P}$ was measured as described above. This procedure separates any organic precipitates from the solution (Tiessen \& Moir, 1993). Organic $\mathrm{P}$ in the bicarbonate and hydroxide extracts was calculated as the difference between total and inorganic $\mathrm{P}$, since organic $\mathrm{P}$ cannot be determined directly. Total $\mathrm{P}$ was analyzed as inorganic $\mathrm{P}$ after digestion with ammonium persulfate and sulfuric acid, followed by autoclavation (Tiessen \& Moir 1993). An aliquot of $1 \mathrm{ml}$ bicarbonate or hydroxide extract was digested with $0.1 \mathrm{~g}$ ammonium persulfate and $2 \mathrm{ml} 0.9 \mathrm{M} \mathrm{H}_{2} \mathrm{SO}_{4}$ in an autoclave for $2 \mathrm{hrs}$. Inorganic $\mathrm{P}$ was determined as described above for the resin and acid extracts.

\subsection{Statistical Analysis}

Data collected were subjected to analysis of variance (ANOVA) using GenStat Discovery Edition 4, 10.3DE statistical software, and where the F-value was found to be significant, the means were separated at $P \leq 0.05$ level of significance using Fisher least significant differences (Genstat, 2011).

\section{Results}

\subsection{Distribution of P Fractions across the Soil Types in the Derived Savanna Zone}

\subsubsection{Dilute Acid Pi}

At the $0-20 \mathrm{~cm}$ depth, the largest accumulation of Ca-P fraction was observed in Katcha series. At the $20-40 \mathrm{~cm}$ depth, increases in this P fraction was observed in Okpanam and Afia Mpko series while at the $40-80 \mathrm{~cm}$ depth, accumulation of Ca-P was observed in Okpanam and Afia Mpko series and decreased at the $80-120 \mathrm{~cm}$ depth (Figure 2). 


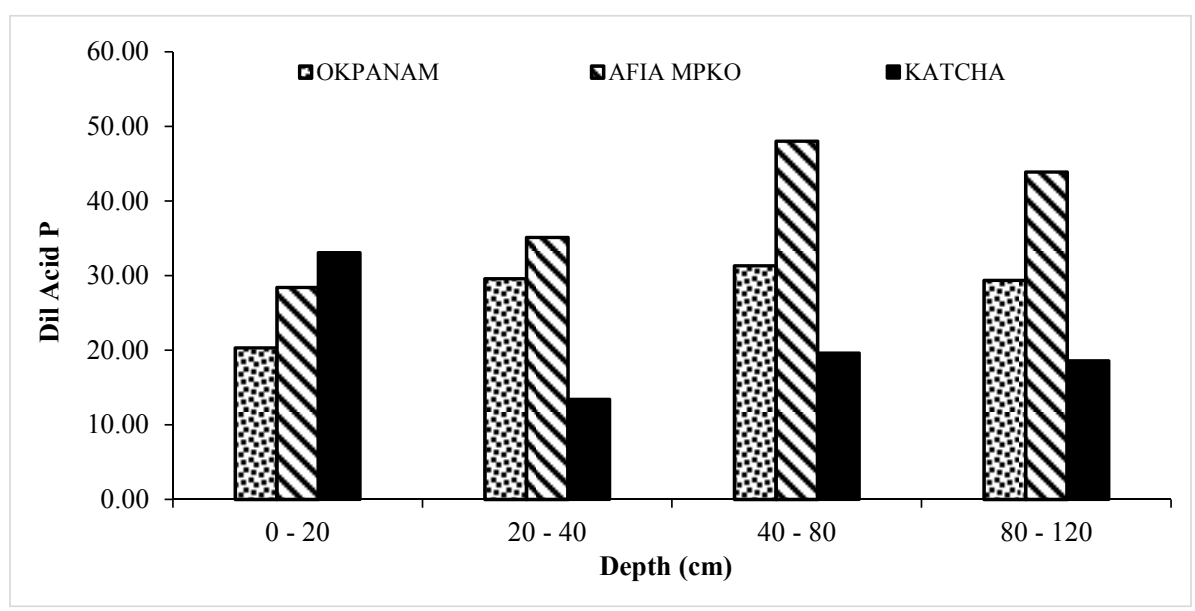

Figure 2. Distribution of dilute acid P down the soil depth across the soil series

\subsubsection{Conc. HCl-Pi}

The recalcitrant $\mathrm{P}$ fraction was initially low at the $0-20 \mathrm{~cm}$ depth while there was no significant increase in the $\mathrm{P}$ fraction at the 20-40 cm depth except in Katcha series which had the largest accumulation of the recalcitrant $P$ fraction. At the 40-80 cm depth, decreases in the P fraction were observed except in Afia Mpko series with a slight increase in the $\mathrm{P}$ fraction. However, at the $80-120 \mathrm{~cm}$ depth, the recalcitrant $\mathrm{P}$ fraction accumulated in Okpanam series but decreased in the other two soil series (Figure 3).

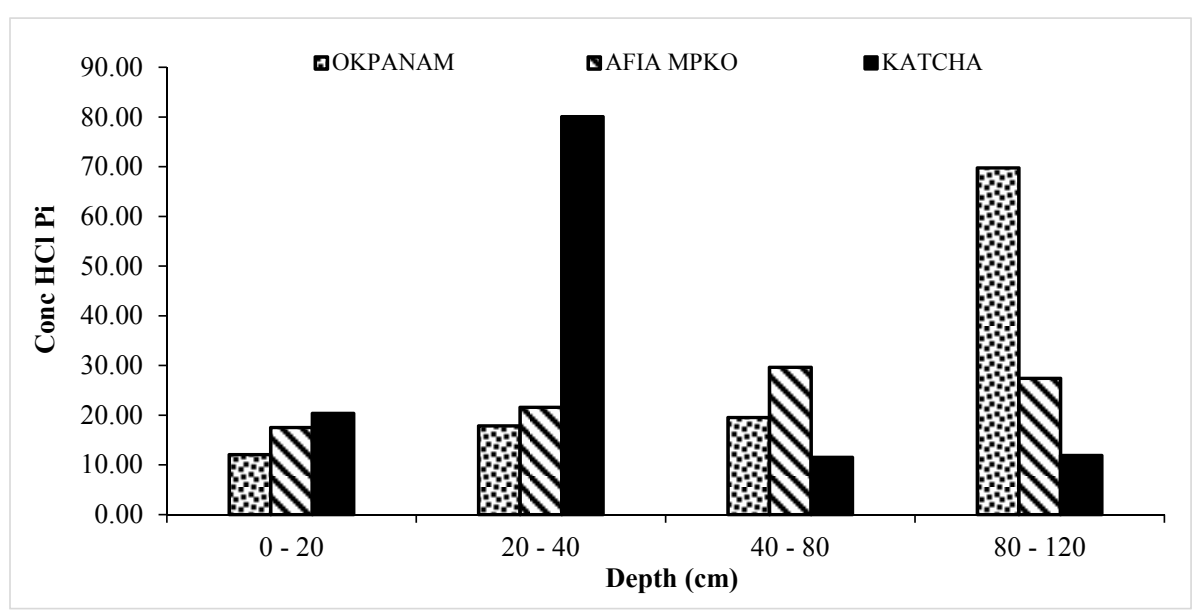

Figure 3. Distribution of conc. HCl Pi down the soil depth across the soil series

\subsubsection{NaOH-Pi}

Variability in the $\mathrm{P}$ fractions was observed for the inorganic $\mathrm{Fe}$ and $\mathrm{Al}-\mathrm{P}$ fraction extractable with $\mathrm{NaOH}$ i.e. the moderately available $P$ fraction across the soil depth. An initial increase was observed in Katcha and Okpanam series at the 0-20 cm depth. However, accumulation of the $\mathrm{P}$ fraction was observed at the $20-40 \mathrm{~cm}$ depth in Katcha series while at the $40-80 \mathrm{~cm}$ depth, the $\mathrm{P}$ fraction tend to accumulate in Afia Mpko seires and decreased in the three soil series characterized at the $80-120 \mathrm{~cm}$ depth (Figure 4). 


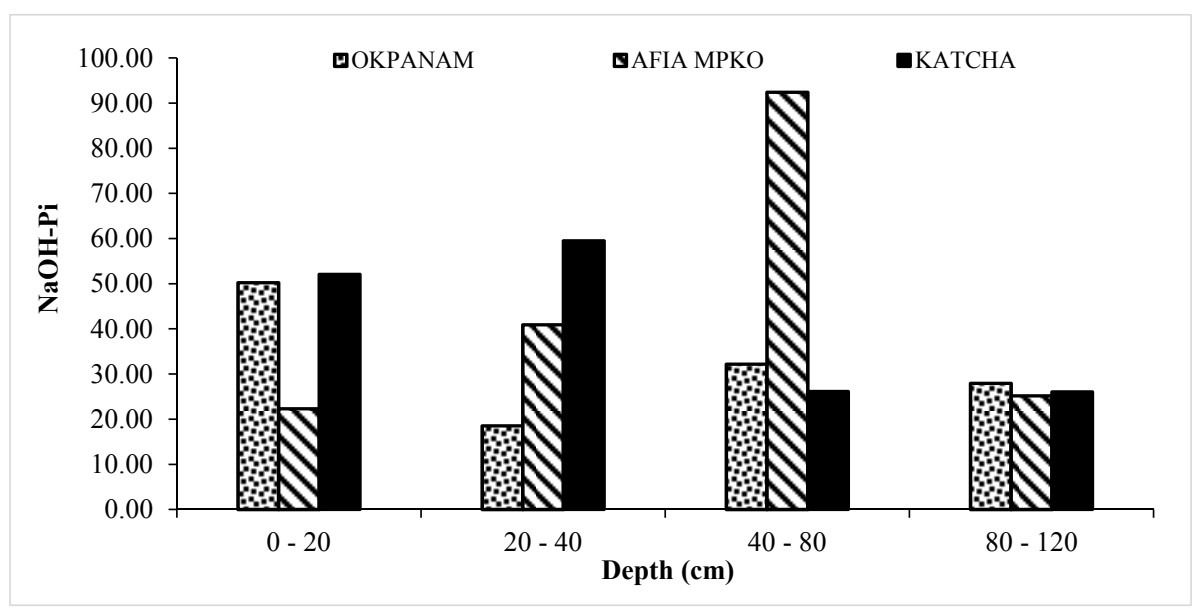

Figure 4. Distribution of $\mathrm{NaOH}-\mathrm{Pi}$ down the soil depth across the soil series

\subsubsection{NaOH-Po}

Accumulation of the organic $\mathrm{P}$ fraction extractable with $\mathrm{NaOH}$ i.e. the moderately available $\mathrm{p}$ fraction was observed in Okpanam and Afia Mpko series at the 0-20 cm depth and decreased at the $20-40 \mathrm{~cm}$ depth. Increase in the $\mathrm{P}$ fraction was later observed at the $40-80 \mathrm{~cm}$ depth and then decreased at the $80-120 \mathrm{~cm}$ depth except in Katcha series which had an accumulation of the organic $\mathrm{P}$ fraction (Figure 5).

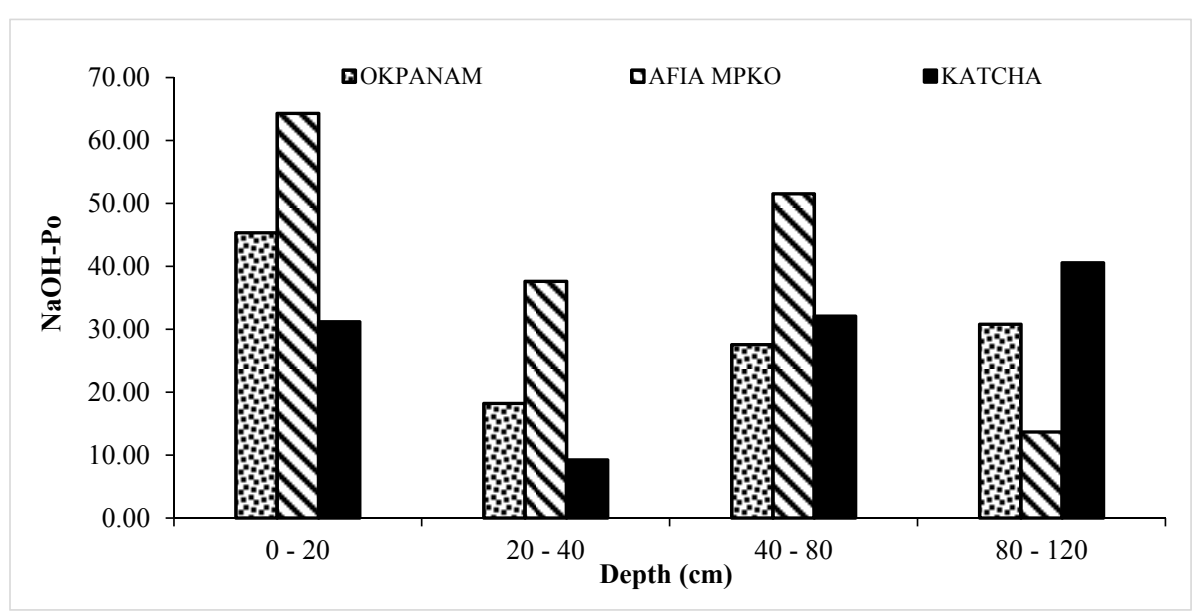

Figure 5. Distribution of NaOH-Po down the soil depth across the soil series

\subsection{5 $\mathrm{NaHCO}_{3}-\mathrm{Pi}$}

The readily available $\mathrm{P}$ fraction extractable with bicarbonate was initially low at the $0-20 \mathrm{~cm}$ depth except in Katcha series. At the 20-40 cm depth, decrease in the P fraction was observed except in Okpanam series with a slight increase in the $\mathrm{P}$ fraction. Accumulation of the inorganic $\mathrm{P}$ fraction was observed at the $40-80 \mathrm{~cm}$ depth in Afia Mpko and Katcha series while the P fraction was observed to later decrease at the 80-120 cm depth but with accumulation of the readily available $\mathrm{P}$ fraction in Okpanam series (Figure 6). 


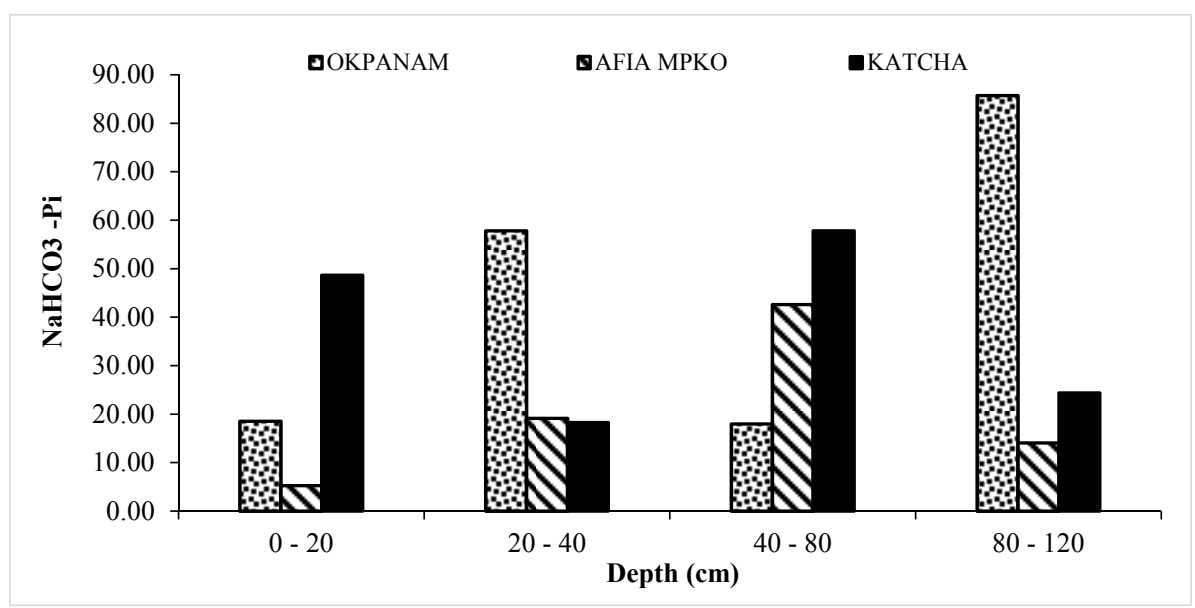

Figure 6. Distribution of $\mathrm{NaHCO}_{3}$-Pi down the soil depth across the soil series

\subsection{6 $\mathrm{NaHCO}_{3}-\mathrm{Po}$}

The moderately available $\mathrm{P}$ fraction i.e. $\mathrm{NaHCO}_{3}-\mathrm{Po}$ was also low initially at the $0-20 \mathrm{~cm}$ depth as observed in the inorganic $\mathrm{P}$ fraction extractable with bicarbonate except in Afia Mpko series which had higher values of the moderately available $\mathrm{P}$ fraction than the readily available $\mathrm{P}$ fraction at the $0-20 \mathrm{~cm}$ depth. The moderately available $P$ fraction continued to increase in Afia Mpko series at the $20-40 \mathrm{~cm}$ depth while further increases in the P fraction were observed at the 40-80 cm depth in Okpanam and Katcha series. Decrease in the P fraction was observed at the 80-120 cm depth, except in Afia Mpko series (Figure 7).

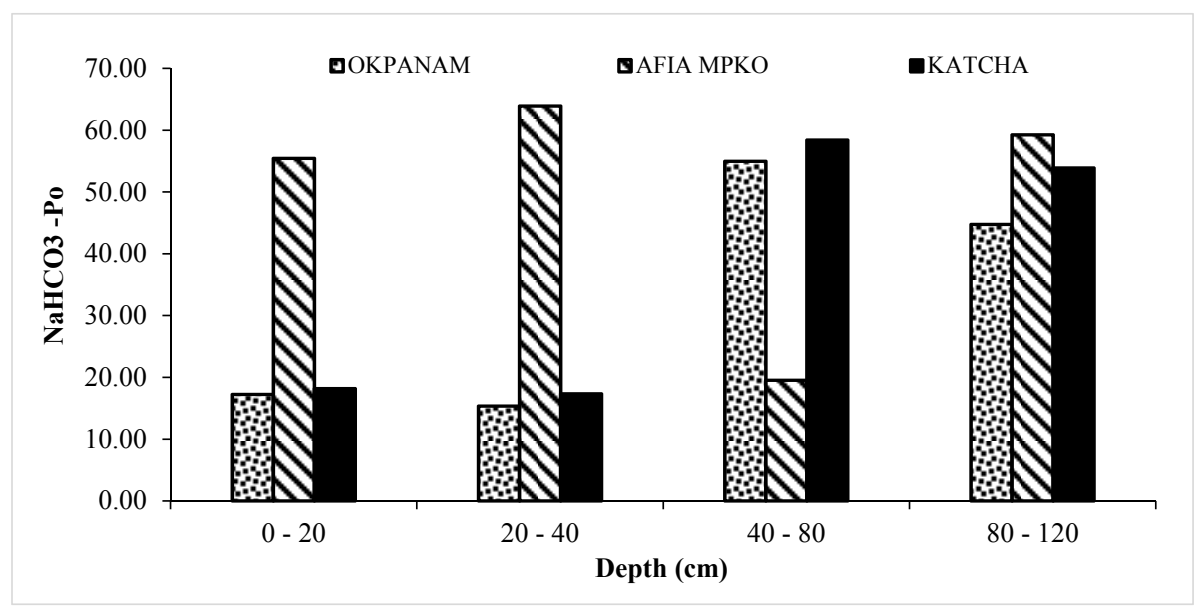

Figure 7. Distribution of $\mathrm{NaHCO}_{3}$-Po down the soil depth across the soil series

\subsubsection{Residual P}

Irrespective of the soil series characterized in this agro-ecological zone, residual $\mathrm{P}$ was the smallest of the $\mathrm{P}$ fraction determined. At the $0-20 \mathrm{~cm}$ depth, accumulation of the $\mathrm{P}$ fraction was observed in Okpanam series while at 20-40 cm depth, residual P accumulation was observed in Afia Mpko and Katcha series. Reduction in the P fraction was later observed down the soil depth to the 80-120 cm depth (Figure 8). 


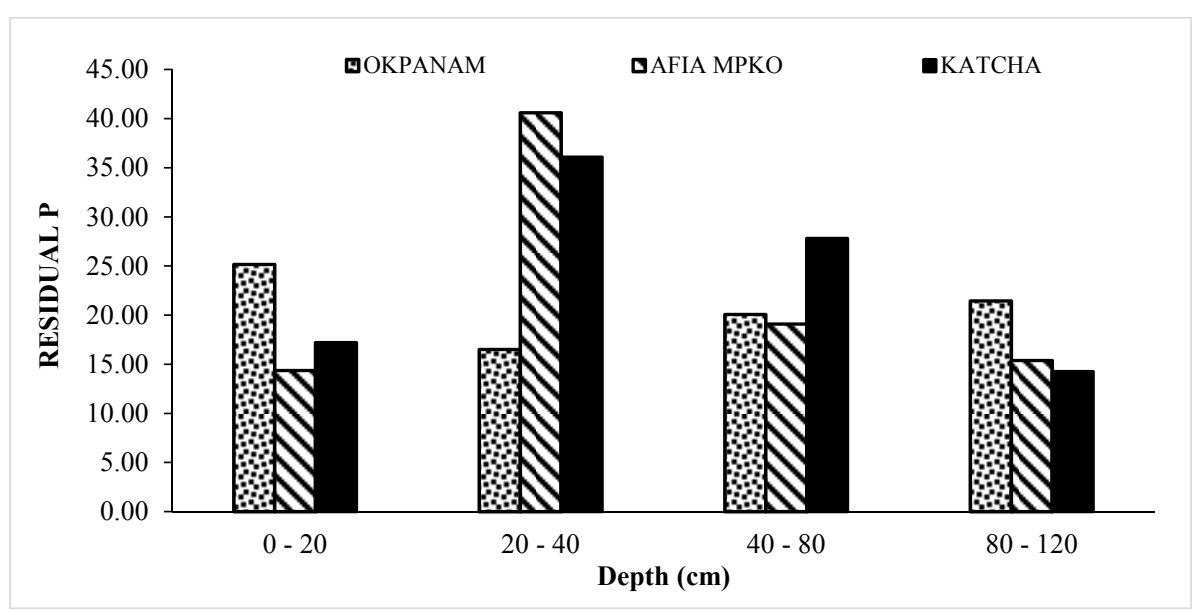

Figure 8. Distribution of residual $\mathrm{P}$ down the soil depth across the soil series

\subsubsection{Resin P}

The readily available $\mathrm{P}$ fraction i.e. resin $\mathrm{P}$ was the largest $\mathrm{P}$ fraction observed and this was evident down the soil depth. However, at the $0-20 \mathrm{~cm}$ depth, the $\mathrm{P}$ fraction was low when compared to the values obtained for the subsurface soil depths. Increase in the resin P fraction was observed at the $20-40 \mathrm{~cm}$ depth, with a little decrease at the $40-80 \mathrm{~cm}$ depth and with the largest increase in the $P$ fraction at the $80-120 \mathrm{~cm}$ depth, which tend to act as the sink of resin $\mathrm{P}$ fraction in this agro-ecological zone (Figure 9).

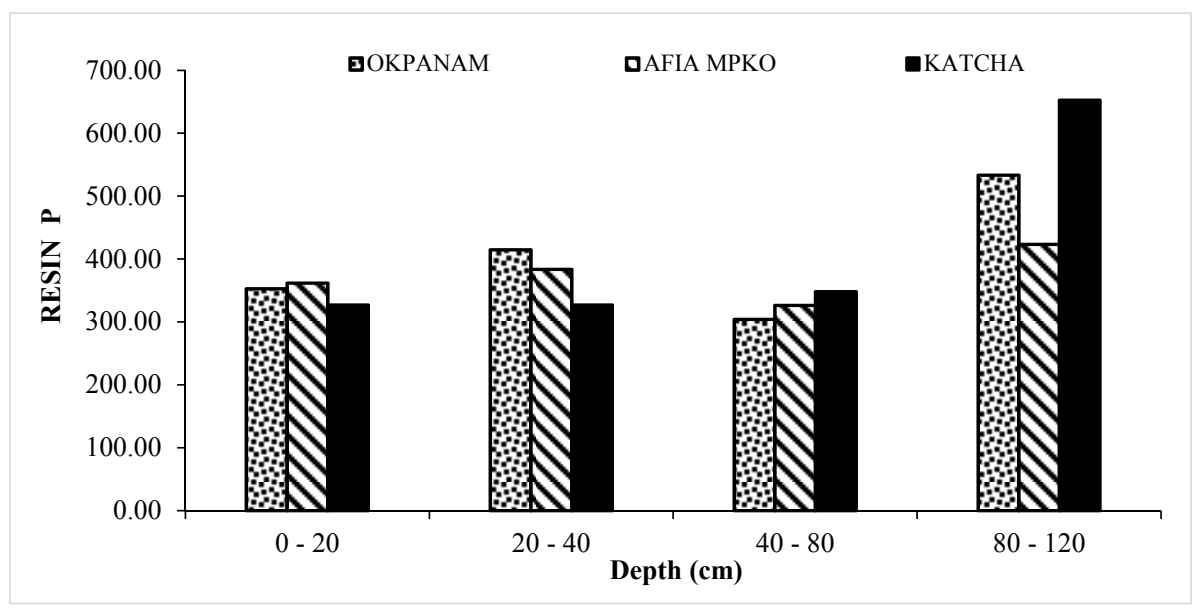

Figure 9. Distribution of resin P down the soil depth across the soil series

\section{Discussion}

Variability in the distribution of all the $\mathrm{P}$ fractions determined occurred down the soil depth. Soils under different land use and management practices have been found to vary in pool sizes and in the distribution of $\mathrm{P}$ within soil profile (Emiru \& Gebrekudan, 2013). Resin P was the largest extractable P fraction in all the soil series characterized while residual $\mathrm{P}$ was the least in abundance. The dilute acid Pi i.e. Ca-P tend to accumulate at the $0-20 \mathrm{~cm}$ depth specifically in Katacha series while this $\mathrm{P}$ fraction increased down to the $40-80 \mathrm{~cm}$ depth in Okpanam and Afia Mpko series. The concentrated HCl-Pi fraction, which represents the stable P fraction was low at the $0-20 \mathrm{~cm}$ depth and increased down to the $20-40 \mathrm{~cm}$ depth in Katcha series while a decrease was observed down to the 80-120 cm depth except in Okpanam series, where conc. HCl-Pi accumulation was observed. The moderately available inorganic $\mathrm{P}$ fraction i.e. NaOH-Pi varied down the soil depth. The NaOH-Pi fraction was initially high at the $0-20 \mathrm{~cm}$ depth, especially in Katcha and Okpanam series and continued to increase down to the 20-40 cm depth in Katcha series and to the 40-80 cm depth in Afia Mkpo series. A decrease in the NaOH-Pi fraction was later observed at the $80-120 \mathrm{~cm}$ depth. The organic $\mathrm{P}$ fraction extractable with 
$\mathrm{NaOH}$ was initially observed at the $0-20 \mathrm{~cm}$ depth and later decreased down to the $20-40 \mathrm{~cm}$ depth. Intermittent increase and decrease was observed down to the $80-120 \mathrm{~cm}$ depth. The moderately available organic $\mathrm{P}$ fraction may be in abundance at the sub-soil horizons because portions of the $\mathrm{P}$ fraction are supplied through weathering of the bedrock (Nobuo et al., 2010). The readily available inorganic and organic $\mathrm{P}$ fraction i.e. $\mathrm{NaHCO}_{3}-\mathrm{Pi}$ and Po was initially low at the $0-20 \mathrm{~cm}$ depth. At $20-40 \mathrm{~cm}$ depth, decrease in the inorganic P fraction was observed but with increase in the organic $\mathrm{P}$ fraction. Increases in $\mathrm{NaHCO}_{3}-\mathrm{Pi}$ and Po was later observed at the $40-80 \mathrm{~cm}$ depth and decreased down to the $80-120 \mathrm{~cm}$ depth. In most tropical soils, with the derived savanna zone inclusive, $\mathrm{P}$ deficiency has necessitated large application of fertilizer $\mathrm{P}$ and recently manure to overcome $\mathrm{P}$ fixation. Past fertilizer application has been observed to be the main factor for the increases observed for the moderately and readily available P fraction. Reddy et al. (1999) has observed that application of fertilizer (fertilizer $\mathrm{P}$ and manure) significantly increased $\mathrm{NaHCO}_{3}-\mathrm{Pi}$, Po as well as the $\mathrm{NaOH}-\mathrm{Pi}$ and Po fractions. The residual $\mathrm{P}$ fraction was low irrespective of the soil series. However, accumulation of the $\mathrm{P}$ fraction was observed at the $0-20 \mathrm{~cm}$ depth and down to the $20-40 \mathrm{~cm}$ depth, varying among the soil series. The resin $\mathrm{P}$ fraction was the largest $\mathrm{P}$ fraction and this tends to be the sink of $\mathrm{P}$ in this agro-ecological zone. The resin $\mathrm{P}$ fraction was initially low at the $0-20 \mathrm{~cm}$ depth but increased down the soil depth. The large amount of resin $\mathrm{P}$ observed would probably be due to past application of inorganic and organic fertilizers in the different soil types. Although, residual $\mathrm{P}$ was the least fraction observed, the sink of $\mathrm{P}$ has been found to be either more in the labile $\mathrm{P}$ fraction (Iyamuremye et al., 1996; Liliefein et al., 1999; Oberson et al., 1999) or in the stable fractions as acid extractable or even residual P (Linquist et al., 1997; Daroub et al., 2000).

\section{Conclusion}

Appropriate management of soil phosphorus fertility relies on sound knowledge about the phosphorus reserve and its bioavailabilty. Phosphorus availability to plants depends on both the inorganic and organic pools in the soil. However, in this study, it was discovered that the pattern of P distribution down the soil depth varied among the soil types in the agro-ecological zone. Resin $\mathrm{P}$ was the largest extractable $\mathrm{P}$ and therefore serves as the sink of $\mathrm{P}$ while residual $\mathrm{P}$ was the smallest $\mathrm{P}$ fraction. Variability was observed down the soil depth in all the soil series characterized. However, NaOH-Pi and Po was in abundance at the $0-20 \mathrm{~cm}$ depth while other $\mathrm{P}$ fractions were observed down the soil depth especially at the 40-80 cm depth.

\section{References}

Beck, M. A., \& Sanchez, P. A. (1994). Soil phosphorus fractions dynamics during 18 years of cultivation on a typic Paleudult. Soil Science Society of American Journal, 58, 1424-1431. https://doi.org/10.2136/ sssaj2000.6451681x

Bunemann, E. K., Heenan, D. P., Marschner, P., \& McNeill, A. M. (2006). Long-term effects of crop rotation, stubble management and tillage on soil phosphorus dynamics. Australian Journal of Soil Research, 44, 611-618. https://doi.org/10.1071/SR05188

Daroub, S. H., Ellis, B. G., \& Robertson, G. P. (2000). Phosphorus fractions and fate of phosphorus-33 in soils managed under plowing and no-tillage. Soil Science Society of America Journal, 51, 1547-1553. https://doi.org/10.2136/sssaj2000.641170x

Emiru, N., \& Gebrekidan, H. (2013). Effect of land use changes and soil depth on soil organic matter, total nitrogen and available phosphorus contents of soils in senbat watershed, Western Ethiopia. Journal of Agricultural and Biological Science, 8(3), 206-212. https://doi.org/10.5194/solid-2-1075-2013

FAO. (2006). Guidelines for soil description (4th ed., p. 102). FAO, Rome, Italy.

GenStat. (2011). GenStat Discovery Edition 4, Release 10.3DE (PC/Windows 7). VSN International Ltd., Rothamsted Experimental Station, Hemel, Hempstead, UK.

Igwe, C. A. (2001). Free oxide distribution in Niger flood plain soils in relation to their total and available phosphorus. Proceedings of the 27th Annual Conference of the Soil Science Society of Nigeria (pp. 196-201).

Iyamuremye, F., \& Dick, R. P. (1996). Organic amendments and phosphorus sorption by soils. Advances in Agronomy, 56, 139-185. https://doi.org/10.1016/S0065-2113(08)60181-9

Linquist, B. A., Singleton, P. W., \& Cassman, K. G. (1997). Inorganic and organic phosphorus dynamics during a build-up and decline of available phosphorus in an ultisol. Soil Science, 162, 254-264. https://doi.org/ 10.1097/00010694-199704000-00003 
Liu, X. L., He, Y. Q., Zhang, H. L., Schroder, J. K., Li, C. L., \& Zhou, J. (2010). Impact of land use and soil fertility on distributions of soil aggregate fractions and some nutrients. Pedosphere, 20(5), 666-673. https://doi.org/10.1016/S1002-0160 (10)60056-2

Loganathan, P., \& Sutton, P. M. (1987). Phosphorus fractions and availability in soils formed on different geological deposits in the Niger Delta area of Nigeria. Soil Science, 143, 16-25. https://doi.org/10.1097/ 00010694-198701000-00003

Moss, R. P. (1957). Report on classification of soils found over sedimentary rocks in Western Nigeria (p. 88). Ibadan, WSMANR.

Mudorch, G., Ojo-Atere, J. O., Colborne, G., Olomu, E. I., \& Odugbesan, E. M. (1976). Soils of the Western State Savanna in Nigeria (p. 145). Land Resources Division, Ministry of Overseas Development, Tolworth Tower, England.

Murphy, J., \& Riley, J. P. (1962). A modified single solution method for the determination of phosphate in natural waters. Analytica Chimica Acta, 27, 31-36. https://doi.org/10.1016/S0003-2670(00)88444-5

Nwoke, O. C., Vanlauwe, B., Diels, J., Sangainga, N., \& Osonubi, O. (2004). The distribution of phosphorus fractions and desorption characteristics of some soils in the moist savanna zone of West Africa. Nutrient Cycling in Agroecosystems, 69(2), 127-141. https://doi.org/10.1023/B.FRES.0000029677.094.24.ef

Oberson, A., Friesen, D. K., Tiessen, H., Morel, C., \& Stahel, W. (1999). Phosphorus status and cycling in native savanna and improved pastures on an acid low-P Colombian Oxisol. Nutrient Cycling in Agroecosystems, 55, 77-88. https://doi.org/10.1023/A:1009813008445

Raji, B. A. (2006). Phosphorus fractions of a Chronosequence of stabilized contiguous sand dune in the semi-arid savanna of Nigeria. International Journal of Soil Science, 1, 64-74. https://doi.org/10.3923/ ijss.2006.64.74

Ridley, J. R. (1984). Forms of phosphorus and their relation to horizonation in selected Iowa soils (M.Sc. Thesis, Iowa State University, Amesterdam).

Tiessen, H., \& Moir, J. O. (1993). Characterization of available P by sequential extraction. In M. R. Carter (Ed.), Soil sampling and methods of analysis (pp. 75-86). Canadian Society of Soil Science, Lewis Publishers, CRC Press, Boca Raton, FL. https://doi.org/10.4141/S00-666

\section{Copyrights}

Copyright for this article is retained by the author(s), with first publication rights granted to the journal.

This is an open-access article distributed under the terms and conditions of the Creative Commons Attribution license (http://creativecommons.org/licenses/by/4.0/). 